\title{
School Well Being Siswa Kota Jambi
}

\author{
Yun Nina Ekawati ${ }^{1}$, Nofrans Eka Saputra ${ }^{2}$ \\ ${ }^{12}$ Jurusan Psikologi, Universitas Jambi, Jambi \\ Email : yun_nina.e@unja.ac.id
}

Submitted : 29/08/2021

Accepted: 10/09/2021

Published: 15/09/2021

\begin{abstract}
This study aims to describe the indicators of a school well-being program in Jambi City. This research was conducted with an open survey method (open ended questionnaire), the analysis was carried out by categorization, axial coding, percentage, and a description of each category. The sampling technique is random sampling. This study included 239 high school students in Jambi City as respondents. The results showed that the indicators of a school well-being consisted of school conditions (having), social relations (loving), school self-fulfillment (being), and health status had been achieved even though in each component there was still unsatisfactory achievement indicator status. The main priority in realizing the development of a school well-being program in Jambi City includes planning to prepare relaxing facilities according to student needs, the role of teachers, constructive collaboration between teachers and parents, and strengthening physical and psychological health services. The implementation of the welfare school program is the responsibility of schools and stakeholders so that it is necessary to prepare for strengthening policies in governance, long-term plans, sources of funds, implementation, and supervision from local, provincial, and even Ministry level agencies.
\end{abstract}

Keywords: program, school well-being, student

\begin{abstract}
Abstrak
Penelitian ini bertujuan mendeskripsikan tentang indikator program sekolah sejahtera di Kota Jambi. Penelitian ini dilakukan dengan metode survei terbuka (open endeed quesioner), analisis dilakukan dengan kategorisasi, axial coding, presentase, dan deskripsi masing-masing kategori. Teknik sampling yaitu random sampling. Responden dalam penelitian ini sebanyak 239 siswa SMA di Kota Jambi. Hasil penelitian menunjukkan bahwa indikator sekolah sejahtera terdiri dari kondisi sekolah (having), hubungan sosial (loving), pemenuhan diri sekolah (being), status kesehatan (health) terah tercapai meskipun dalam setiap komponen masih ada status indikator capaian yang belum memuaskan. Prioritas utama dalam mewujudkan pengembangan program sekolah sejahtera di Kota Jambi mencakup perencanan dalam mempersiapkan fasilitas santai sesuai kebutuhan siswa, peran guru, kolaborasi konstruktif guru dan orangtua, serta penguatan layanan kesehatan fisik dan psikologis. Implementasi program sekolah sejahtera menjadi tanggung jawab sekolah dan stakeholder sehingga perlu persiapan penguatan kebijakan dalam tata kelola, rencana jangka panjang, sumber dana, implementasi, dan pengawasan dari instansi level daerah, provinsi, bahkan Kementerian.
\end{abstract}

Kata kunci : program, sekolah sejahtera, siswa

\section{PENDAHULUAN}

Sekolah termasuk kontek

perkembangan siswa sebagai remaja dalam meningkatkan kapasitas kognitif, sosial dan emosional. Sekolah berkewajiban menyediakan lingkungan yang aman dan merangsang siswa untuk berjuang dan memiliki harapan dalam pencapaian pembelajaran akademik dan keterampilan hidup.

Siswa menghabiskan banyak waktu disekolah dengan melakukan belajar di kelas maupun kegiatan ekstrakulikuler. Waktu yang dihabiskan kurang lebih 6-8 jam sehari atau 30 jam perminggu. Dalam 
jangka waktu yang cukup lama di sekolah tersebut siswa berinteraksi bersama teman sebaya, guru bahkan pengelola sekolah. Hal ini membutuhkan pola interaksi yang sehat dalam setiap aktivitas tersebut.

Interaksi siswa dengan teman sebaya memiliki resiko terhadap hadirnya perilaku berisiko pada siswa. Fadzlul et al (2016) menunjukkan bahwa perilaku bullying, merokok, perilaku seksual dan penggunaan napza merupakan perilaku berisiko yang dilakukan oleh remaja disebabkan pengaruh teman sebaya. Akses mendapatkan rokok dan narkoba serta desakan teman sebaya untuk menggunakannya merupakan risiko remaja dalam bergaul sesama teman sebaya. Hal ini diperparah bahwa teman sebaya bisa menjadi sebagai pelaku utama bullying disekolah.

Sisi lain, interaksi antara guru dan siswa memiliki juga memiliki risiko. Muis (2017) menunjukkan bahwa siswa menjadi korban kekerasan di sekolah, seperti kekerasan verbal, psikologis, fisik. Sebagian besar siswa yang menjadi korban cenderung pasrah terhadap kekerasan tersebut, hanya sebagian kecil $(10,6 \%)$ merasa dendam. Paradigma dan wawasan untuk menegakkan disiplin harus dengan kekerasan adalah alasan guru dalam hal tersebut.

Secara empiris, sekolah berpengaruh dalam membentuk identitas diri remaja. Lingkup sekolah memberikan prinsip pembelajaran yang ideal bagi tumbuhnya identitas diri remaja. Semakin baik penguatan yang diberikan sekolah maka fase kekacauan identitas yang terjadi pada remaja akan dilewati dengan sukses tanpa berdampak terjerumusnya siswa untuk melakukan perilaku berisiko.

Jessor (1993) menjelaskan bahwa sekolah termasuk dalam faktor protektif (protective factor) dan risiko (risk factor). Sekolah bisa menjadi pelindung siswa dalam mencapai tahap perkembangan ideal, namun bukan tidak mungkin menjadi faktor risiko untuk mengarahkan siswa melakukan perilaku berisiko. Hal ini diperlukan keterlibatan sekolah untuk melindungi siswa dari perilaku berisiko sehingga siswa merasakan kesejahteraan psikologis.

Allardt (A. Konu \& Rimpelä, 2002) menjelaskan bahwa kesejahteraan merupakan kondisi dimana dimungkinkan bagi manusia untuk memenuhi kebutuhan dasarnya. Dalam sistim indikator kesejahteraan, baik kebutuhan dasar manusia maupun material harus dipertimbangkan. Allardt membagi kebutuhan dasar manusia menjadi tiga kategori yaitu memiliki (having), mencintai (loving), menjadi (being). Having mengacu pada kondisi material dan kebutuhan pribadi dalam perspektif yang luas. Loving berarti kebutuhan untuk berhubungan dengan orang lain dan untuk membentuk identitas sosial. Being menunjukkan kebutuhan untuk pertumbuhan pribadi yaitu integrasi ke dalam masyarakat dan hidup selaras dengan alam.

Lebih lanjut, konsep sekolah sejahtera yang dihubungkan dengan pengajaran dan pendidikan, disatu sisi dengan pembelajaran dan disisi lain dengan prestasi. Sekolah sejahtera dibagi menjadi 4 (empat) dimensi yaitu kondisi sekolah (having), social relationship (loving), means for selffulfilment (being), dan health status (A. Konu \& Rimpelä, 2002).

Kesejahteraan psikologis siswa dapat diwujudkan melalui program sekolah sejahtera (Hidayah et al., 2016). Program sekolah sejahtera di Indonesia dilakukan oleh Center for Public Mental Health Fakultas Psikologi Universitas Gadjah Mada bekerjasama dengan stakeholder yang bertujuan untuk meminimalkan kenakalan peserta didik dengan melibatkan guru, orangtua, dan masyarakat. Kriteria sekolah sejahtera harus memenuhi setidaknya empat persyaratan utama yaitu kondisi sekolah yang sehat dan lingkungan kondusif, interaksi yang baik di antara anggota sekolah, kesempatan siswa untuk self-actualization, potensi pengembangan, 
dan kondisi mental serta fisik yang baik (Hidayah et al., 2016).

Indonesia memiliki fakta yang beragam dalam penerapan program sekolah sejahtera. Penelitian Khatimah (2015) menjelaskan bahwa kesejahteraan siswa sekolah akselerasi di SMA digambarkan pada infrastuktur sekolah yang baik, modal individu yang sangat baik, desain manajemen pembelajaran yang tidak sehat, interaksi antar pribadi yang baik di sekolah, manajemen sekolah yang baik, dan persepsi dukungan orang tua.

Penelitian Hidayah et al (2016) menunjukkan bahwa kesejahteraan siswa di sekolah secara psikologis tinggi pada dimensi status kesehatan, tetapi rendah pada dimensi memiliki (having), mencintai (loving) dan menjadi (being). Temuan lainya adalah ada kecenderungan intimidasi verbal, fisik, dan seksual yang dilakukan oleh teman sekelas dan guru mereka secara pribadi.

Penelitian Fatmawati (2018) menjelaskan bahwa faktor pendukung program sekolah sejahtera di SMA Negeri 1 Godean yaitu adanya komitmen dan tanggung jawab agen-agen pelaksana program, warga sekolah yang terbuka dengan adanya program baru, adanya pihak luar sekolah yang ikut membantu dalam pelaksanaan program yaitu Center Public Mental Health UGM, sarana prasarana yang dimiliki sekolah, sedangkan faktor penghambat program yaitu dana dan waktu.

Berdasarkan uraian masalah diatas maka penelitian ini diajukan untuk mendeskripsikan indikator program sekolah sejahtera pada sekolah menengah umum yang berada di Kota Jambi dengan harapan dapat melakukan implementasi program tersebut dan mengetahui faktor-faktor yang mempengaruhi hal tersebut.

\section{METODE PENELITIAN Partisipan Penelitian}

Penelitian ini melibatkan sebanyak 239 responden di Kota Jambi. Teknik pengampilan sampling yaitu random sampling. Responden berjenis kelamin lakilaki $(\mathrm{n}=57)$ dan perempuan $(\mathrm{n}=182)$ yang merupakan siswa -siswi sekolah menengah umum di Kota Jambi. Siswa mengetahui kondisi sekolah, hubungan sosial yang terjadi di sekolah, pemenuhan diri sekolah, status kesehatan.

\section{Instrumen Penelitian}

Instrumen yang peneliti gunakan dalam penelitian ini dikembangkan oleh tim peneliti dengan menggunakan pertanyaan survei terbuka (open endeed questionnaire). Dalam menyusun pertanyaan terbuka tersebut, peneliti melakukan diskusi dengan tim, para ahli, dan siswa di Kota Jambi sebagai responden penelitian untuk menanyakan apakah pertanyaan tersebut bisa dipahami.

\section{Analisis Data}

Data dianalisis menggunakan kategorisasi (coding), axial coding, dan melakukan tabulasi dan persentase terhadap jumlah respon yang dijawab oleh responden. Setelah mendapat hasil kategori dan persentase, peneliti mendeskripsi hasil penelitian berdasarkan kategori yang telah dianalisis oleh peneliti.

\section{HASIL DAN PEMBAHASAN}

Kriteria sekolah sejahtera setidaknya harus memenuhi syarat seperti kondisi sekolah yang sehat dan lingkungan kondusif, interaksi yang baik di antara anggota sekolah, kesempatan siswa untuk self-actualization, potensi pengembangan, dan kondisi mental serta fisik yang baik (Hidayah et al., 2016; A. I. Konu \& Lintonen, 2006; A. Konu \& Rimpelä, 2002). Penelitian ini menggambarkan kriteria sekolah sejahtera telah mencakup empat komponen yaitu kondisi sekolah (having), hubungan sosial (loving), pemenuhan diri (being), dan status kesehatan (health), meskipun dalam setiap komponen masih ada status indikator capaian yang belum memuaskan. 
Kondisi sekolah dijabarkan melalui beberapa indikator yaitu kepadatan kelas, kebisingan, ventilasi yang buruk, suhu kualitas udara, pencahayaan yang kurang, kotoran/ debu di meja, fasilitas yang buruk, kegelisahan dalam kelas, tekanan waktu dalam kelas, insiden kekerasan, risiko kecelakaan, risiko kehilangan (hp, sepeda motor, uang dalam tas), waktu istirahat yang tidak cukup. Kondisi sekolah yang berdampak terhadap pekerjaan sekolah dijabarkan dalam tabel 1 .

Tabel 1. Kondisi Sekolah yang berdampak gangguan pada pekerjaan sekolah

\begin{tabular}{llcc}
\hline \multicolumn{1}{c}{ Indikator Gangguan } & Kategori & f & \% \\
\hline Gangguan karena Kepadatan Kelas & Sedikit & 126 & 52.7 \\
Gangguan karena Kebisingan & Sedikit & 90 & 37.7 \\
Gangguan karena Ventilasi yang buruk & Sedikit & 77 & 32.2 \\
Gangguan karena Suhu terlalu panas & Sedikit & 109 & 45.6 \\
Gangguan karena Pencahayaan yang kurang & Sedikit & 91 & 38.1 \\
baik & & & \\
Gangguan karena Ruangan Kotor/ Berdebu & Sedikit & 86 & 36 \\
Gangguan karena Meja yang rusak & Sedikit & 83 & 34.7 \\
Gangguan karena Kursi yang rusak & Cukup & 79 & 33.1 \\
& Banyak & & \\
Gangguan karena Kegelisahan dalam kelas & Sedikit & 99 & 41.4 \\
Gangguan karena Tekanan waktu dalam kelas & Sedikit & 100 & 41.8 \\
Gangguan karena Insiden Kekerasan dalam & Sedikit & 77 & 32.2 \\
kelas & & & \\
Gangguan karena Risiko kecelakaan & Sedikit & 87 & 36.4 \\
Gangguan karena Risiko kehilangan & Sedikit & 70 & 29.3 \\
Gangguan karena Waktu istirahat tidak cukup & Sedikit & 80 & 33.5 \\
Gangguan karena Keributan dalam kelas & Sedikit & 97 & 40.6 \\
\hline
\end{tabular}

Sisi lain, kelengkapan layanan juga mempengaruhi kegiatan pembelajaran fasilitas sekolah seperti layanan bagi siswa. Tabel 2 menjabarkan perpustakaan, laboratorium, kantin, layanan kelengkapan fasilitas layanan di sekolah. konseling, layanan UKS, sanitasi/ toilet

Tabel 2. Kelengkapan Fasilitas Layanan sekolah

\begin{tabular}{llcc}
\hline $\begin{array}{l}\text { Kelengkapan Fasilitas } \\
\text { Layanan Sekolah }\end{array}$ & Kategori & f & \% \\
\hline Fasilitas Layanan Perpustakaan & Lengkap & 102 & 42.7 \\
Fasilitas Layanan Kantin & Lengkap & 108 & 45.2 \\
Fasilitas Layanan UKS & Lengkap & 112 & 46.9 \\
Fasilitas Toilet & Cukup Lengkap & 105 & 43.9 \\
Fasilitas Santai & Tidak Lengkap & 91 & 38.1 \\
Fasilitas Layanan Konseling & Lengkap & 104 & 43.5 \\
Fasilitas Laboratorium & Lengkap & 110 & 46 \\
\hline
\end{tabular}

Dalam komponen kondisi sekolah (having) menunjukkan bahwa kursi yang rusak memiliki dampak gangguan cukup banyak terhadap pekerjaan sekolah menurut siswa, sedangkan permasalahan lain masih sedikit mempengaruhi pekerjaan sekolah 
bagi siswa. Fasilitas toilet yang perlu dibenahi \& fasilitas santai yang tidak lengkap menjadi masalah dalam mewujudkan sekolah sejahtera.

Fasilitas sekolah yang baik berpotensi meningkatkan prestasi akademik siswa (Owoeye \& Yara, 2011). Persepsi siswa terhadap sekolah dengan infrastruktur berkualitas buruk mempengaruhi kesejahteraan psikologis siswa tersebut. Infrastruktur yang buruk membuat kesejahteraan psikologis siswa menjadi rendah (Cuyvers et al., 2011). Fasilitasfasilitas yang mempengaruhi kepuasan dan performa siswa yaitu fasilitas toilet, ventiasi, suhu, pencahayaan, dan tingkat kebisingan, TIK terintegrasi (Cuyvers et al., 2011; A. I. Konu \& Lintonen, 2006)

Lebih lanjut Barret et al (2018) menjelaskan bahwa kepadatan kelas yang optimal, rentang waktu sekolah yang optimal, penjadwalan penggunaan ruangan yang optimal memiliki efek positif terhadap hasil akademik siswa, meskipun setiap sekolah diharapkan memiliki parameternya sendiri yang digunakan untuk memaksimalkan fasilitas sekolah yang mereka miliki. Hal ini menjelaskan bahwa kondisi fisik yang dimiliki sekolah bisa dimanfaatkan lebih optimal dengan berbagai strategi perencanaan pembelajaran yang sesuai kebutuhan siswa, serta sekolah diharapkan memiliki perencanaan pengembangan fasilitas yang lebih terukur, menetapkan prioritas sesuai alokasi dana yang tersedia.

Penelitian ini juga menjabarkan hubungan sosial mencakup hubungan siswa dan guru, hubungan dengan sekolah, dinamika kelompok, bullying, kerja sama antara sekolah dan rumah. Hal ini dijabarkan dalam tabel 3.

Tabel 3. Hubungan Sosial Sekolah

\begin{tabular}{llcc}
\hline \multicolumn{1}{c}{ Indikator Hubungan Sosial } & Kategori & F & \% \\
\hline Apresiasi oleh guru & Pernah dilakukan & 149 & 62.3 \\
Perlakuan adil oleh guru & Pernah dilakukan & 131 & 54.8 \\
Menikmati kebersamaan di kelas & Selalu dilakukan & 144 & 60.3 \\
Bekerja sama dalam tim & Tidak Masalah & 117 & 49 \\
Berinteraksi dengan teman & Tidak Masalah & 157 & 65.7 \\
Berinteraksi dengan guru & Tidak Masalah & 156 & 65.3 \\
Mengikuti pelajaran & Tidak Masalah & 141 & 59 \\
Mengerjakan tugas/ PR & Sedikit Masalah & 115 & 48.1 \\
Mempersiapkan ujian & Sedikit Masalah & 113 & 47.3 \\
Menemukan metode belajar & Sedikit Masalah & 106 & 44.4 \\
Penulisan tugas & Tidak Masalah & 150 & 62.8 \\
Membaca referensi & Tidak Masalah & 142 & 59.4 \\
Menemui guru saat jam pelajaran & Tidak Masalah & 144 & 60.3 \\
Intimidasi selama semester ini & Tidak Pernah & 208 & 87 \\
Berkelahi dengan siswa lainya & Tidak Pernah & 194 & 81.2 \\
\hline
\end{tabular}

Permasalahan dalam komponen hubungan sosial (loving) yang menjadi perhatian (tabel 3) dalam mewujudkan sekolah sejahtera adalah sulitnya siswa dalam bekerja sama dalam tim, sulitnya dalam mengerjakan tugas, sulitnya siswa dalam mempersiapkan ujian, dan sulit menemukan metode belajar yang tepat bagi dirinya. Dinamika hubungan sosial (loving) antara siswa dam teman sebaya memiliki pengaruh terhadap pembelajaran sehingga mempengaruhi keberhasilan dalam mengikuti kelas dan tugas. 
Umpan balik dari dukungan teman sebaya mendorong siswa dalam mengikuti pembelajaran di sekolah. Interaksi teman sebaya dapat mengembangkan pola pikir dan keyakinan dalam menghadapi pendidikan di sekolah. Pola pikir siswa yang baik mempengaruhi perasaan dan cara bertindak di sekolah. Jika di kelas siswa fokus pada pengembangan pola pikir melalui pembelajaran maka siswa akan merasakan kesejahteraan emosional (McLaughlin, 2008)

Keterhubungan antara siswa dengan sekolah yang tinggi juga mendorong siswa untuk mendapatkan pencapaian akademik yang tinggi, dekat dengan teman sebaya, terlibat dalam kegiatan akademik dan memiliki kesejahteraan emosional (Lohmeier \& Lee, 2011). Keyes \& Waterman (2008) menambahkan bahwa dukungan dari teman akan lebih membuat siswa merasakan kebahagaiaan dan kesejahteraan di sekolahnya. Pemahaman ini menjabarkan bahwa hubungan sosial dapat terjadi jika siswa merasa memiliki hubungan yang baik dengan sekolah sehingga merasakan keakraban dengan teman sebaya dan mampu terlibat dalam kegiatan akademik yang berorientasi mengembangkan pola pikir dan keyakinan dalam menghadapi pembelajaran di kelas dan tugas di rumah.

Komponen hubungan sosial (loving) menjabarkan aspek pembimbingan atau motivasi guru dan pengalaman belajar siswa yang saling terkait dengan komponen pemenuhan diri (being). Tidak konsistennya guru dalam memberikan waktu luang bagi siswa untuk belajar di luar kelas, oknum guru pilih kasih terhadap siswa, guru menghukum siswa dengan kekerasan verbal, kurangnya konsistensi guru untuk menggunakan metode yang nyaman dalam belajar dan kurangnya guru memberikan sumber belajar yang beragam, guru terlalu berharap banyak dari siswa dalam belajar, guru mengajar dengan terburu-buru.

Secara ideal, guru seharusnya berperan dalam mengembangkan kecakapan personal siswa melalui konseling/ pembimbingan sehingga siswa menjadi pribadi yang berkembang secara penuh (Supriatna, 2017).

Jika pembimbingan tidak dilakukan maka masalah-masalah ini sebenarnya menjelaskan bahwa hubungan sosial (loving) antara guru dan siswa yang tidak konsisten yang berdampak pemenuhan diri (being) siswa menjadi lemah. Guru memiliki peran penting dalam mengakomodasi antara loving dan being. Guru sebaiknya lebih mengorganisasi lingkungan belajar siswa dan lebih mampu mengelola kelas dengan maksimal. Lingkungan belajar sudah seharusnya diatur dan diawasi agar kegiatan belajar lebih terarah pada tujuan-tujuan pendidikan.

Siswa perlu diberikan rangsangan dan tantangan dalam belajar, serta mendapatkan rasa aman dan kepuasan dalam mencapai tujuan pembelajaran (Gilman \& Huebner, 2003). McLaughlin (2008) menambahkan bahwa kesejahteraan positif dapat dihasilkan melalui pengajaran efektif yang menarik oleh guru, penilaian yang otentik, ruang kelas yang demokratis dan manajemen perilaku yang manusiawi dan konsisten.

Lebih lanjut, komponen pemenuhan diri (being) (tabel 4) terdiri dari masalah berupa lemahnya kontribusi orangtua, guru dan masyarakat bagi siswa yang dijabarkan melalui kurangnya pertemuan sekolah dan orangtua yang hanya dilakukan dalam laporan semester saja, sulitnya siswa menemui dokter di sekolah, kurang bersedianya membicarakan permasalahan pribadi mereka di sekolah. Dalam pemenuhan diri (being) siswa maka faktor komunikasi menjadi aspek penting untuk dijelaskan lebih lanjut. 
Tabel 4. Pemenuhan Diri Siswa

\begin{tabular}{llcc}
\hline \multicolumn{1}{c}{ Indikator Pemenuhan Diri Siswa } & \multicolumn{1}{c}{ Kategori } & f & \% \\
\hline Guru & & & \\
Menggunakan metode mengajar yang nyaman & Kadang-kadang & 143 & 59.8 \\
Memberikan sumber belajar yang beragam & Kadang-kadang & 109 & 45.6 \\
Memberikan waktu luang bagi siswa untuk & Kadang-kadang & 108 & 45.2 \\
belajar & & & \\
Pilih kasih terhadap siswa & Pernah dilakukan & 109 & 45.6 \\
Memberikan kesempatan kepada siswa & Pernah dilakukan & 152 & 63.6 \\
mengeluarkan pendapat & & & \\
Terlalu berharap banyak dari siswa dalam & Kadang-kadang & 116 & 48.5 \\
belajar & & & \\
Memperlakukan setiap kelas sesuai karakternya & Pernah dilakukan & 139 & 58.2 \\
Mengajar dengan terburu-buru & Kadang-kadang & 96 & 40.2 \\
Menghukum dengan kekerasan fisik & Tidak Pernah & 144 & 60.3 \\
Menghukum siswa dengan kekerasan verbal & Pernah dilakukan & 93 & 38.9 \\
Sopan dengan siswi perempuan & Selalu dilakukan & 129 & 54 \\
Membuat jadwal berubah-ubah & Kadang-kadang & 113 & 47.3 \\
Sekolah & & & \\
Memberikan fasilitas bagi siswa sesuai minat & Dilakukan & 99 & 41.4 \\
bakat & & & \\
Memberikan apresiasi penghargaan & Pernah dilakukan & 160 & 66.9 \\
Mendapatkan bantuan untuk masalah di sekolah & Pernah dilakukan & 157 & 65.7 \\
dan pelajaran & & & \\
Mendapatkan penghargaan dan penghormatan & Pernah dilakukan & 180 & 75.3 \\
Menerapkan tata tertib & Diterapkan & 129 & 54 \\
Mengikuti kegiatan intra dan ekstrakurikulum & Pernah dilakukan & 91 & 38.1 \\
Bakti sosial bersama sekolah dan masyarakat & Pernah dilakukan & 99 & 41.4 \\
Bazar bersama Sekolah dan masyarakat & Pernah dilakukan & 108 & 45.2 \\
Mengundang komunitas pada acara tertentu & Pernah dilakukan & 109 & 45.6 \\
Hubungan antara sekolah orangtua & Hanya laporan & 137 & 57.3 \\
$\begin{array}{ll}\text { Mendapatkan bantuan untuk mengerjakan tugas } \\
\text { Menemui dokter dan perawat di sekolah }\end{array}$ & Jarang & 106 & 44.4 \\
Membicarakan permasalahan pribadi di sekolah & Agak sulit & 98 & 41 \\
\hline & Agak puas & 123 & 51,5 \\
\hline
\end{tabular}

Kolaborasi guru dan orangtua dalam komunikasi mendorong siswa menjadi lebih sejahtera secara psikologis (Kuusimäki et al., 2019). Komunikasi yang dibangun menjadi umpan balik yang berguna bagi guru dan orangtua dalam mengembangkan potensi siswa. Komunikasi dalam pendidikan siswa di sekolah terkait tiga kategori umpan balik yang harus diungkapkan oleh guru yaitu masalah yang terkait dengan studi, masalah perilaku dan masalah sensitif. Guru sebaiknya memiliki kepekaan dalam membangun umpan balik tersebut, bukan hanya lebih korektif dan penekanan pada kelemahan anak, namun mampu memberikan komunikasi yang menggembirakan kepada orangtua mengenai keberhasilan-keberhasilan yang telah siswa capai di sekolah (Kuusimäki et al., 2019).

Palt \& Harro-Loit (2015) menjelaskan bahwa guru sebaiknya mengetahui jenis orangtua dalam membangun komunikasi. Orangtua yang bersikap normatif 
dipengaruhi oleh pengalaman dan ingatan mereka sebelumnya. Dalam kasus orangtua yang berfokus pada masalah, maka lebih bermanfaat untuk mengetahui apa yang sulit bagi mereka dan bagaimana perasaan mereka dalam situasi komunikasi tersebut. Dengan mempertimbangkan jenis orangtua ini diharapkan memperkuat kolaborasi antara sekolah dan orangtua.

Upaya membangun komunikasi sekolah yang kuat antara kolaborasi guru, siswa dan orangtua bisa menggunakan akses internet sebagai perantara untuk berkomunikasi. Email dan telepon menjadi pilihan ketika memerlukan komunikasi dua arah yang baik, berhubung sms dan buletin sekolah sudah jarang digunakan. Secara empiris, penggunaan media sosial dalam bentuk grup chat telah banyak dilakukan oleh guru di sekolah, namun informasi yang diberikan hanya sebatas informasi anak/ siswa di sekolah.

Penggunaan media lain seperti LMS (learning management system) menjadi alternatif pilihan yang bisa digunakan saat ini. Dalam penggunaan LMS, Guru lebih proaktif dalam menghubungi daripada orangtua. Guru berkomunikasi satu hingga enam kali perminggu, sedangkan orangtua hanya tiga kali perminggu (Laho, 2019).

Orangtua dengan aktivitas komunikasi yang rendah biasanya sangat memperhatikan nilai dan masalah kesehatan anaknya. Orangtua dengan aktivitas komunikasi yang aktif lebih membahas sistem umpan balik dan evaluasi yang diberikan oleh guru. Pola yang berbeda ini memungkinkan guru dalam menerapkan strategi komunikasi yang berbeda secara efisien dalam melibatkan orangtua dalam mendukung perkembangan anak mereka (Palt \& Harro-Loit, 2015). Penelitian ini juga menunjukkan status kesehatan mencakup riwayat penyakit yang dialami siswa selama 6 bulan dijabarkan dalam tabel 5.

Tabel 5. Status Kesehatan siswa 6 (enam) bulan sekali

\begin{tabular}{lll}
\hline Indikator Status Kesehatan & f & \% \\
\hline Penyakit infeksi pernafasan & & \\
$\quad$ - Sesekali & 16 & 6.7 \\
$\quad$ - Sering & 3 & 1.3 \\
$\quad$ - Selalu & 1 & 0.4 \\
Sakit Leher/ Bahu & & \\
$\quad$ - Satu kali dalam sebulan & 46 & 19.2 \\
- Beberapa kali dalam sebulan & 54 & 22.6 \\
- Satu kali dalam seminggu & 10 & 4.2 \\
Nyeri Punggung & & \\
- Satu kali dalam sebulan & 54 & 22.6 \\
- Beberapa kali dalam sebulan & 39 & 16.3 \\
- Satu kali dalam seminggu & 12 & 5 \\
Sakit Perut & & \\
$\quad$ - Satu kali dalam sebulan & 92 & 38.5 \\
- Beberapa kali dalam sebulan & 77 & 32.2 \\
- Satu kali dalam seminggu & 18 & 7.5 \\
Ketegangan atau Kecemasan & & \\
- Satu kali dalam sebulan & 22 & 9.2 \\
- Beberapa kali dalam sebulan & 18 & 7.5 \\
- Satu kali dalam seminggu & 3 & 1.3 \\
\hline
\end{tabular}




\begin{tabular}{cll}
\hline Iritasi & & \\
- Satu kali dalam sebulan & 22 & 9.2 \\
- Beberapa kali dalam sebulan & 18 & 7.5 \\
- Satu kali dalam seminggu & 3 & 1.3 \\
Sakit Kepala & & \\
- Satu kali dalam sebulan & 61 & 25.5 \\
- Beberapa kali dalam sebulan & 89 & 37.2 \\
- Satu kali dalam seminggu & 21 & 8.8 \\
Flu & & \\
- Satu kali dalam sebulan & 78 & 32.6 \\
- Beberapa kali dalam sebulan & 28 & 11.7 \\
- Satu kali dalam seminggu & 7 & 2.9 \\
\hline
\end{tabular}

Komunikasi dalam masalah kesehatan fisik dan psikologis juga menjadi perhatian. Sekolah-sekolah masih sulit memberikan penguatan pada layanan ini. Sekolah masih mengharapkan Pusat Kesehatan Masyarakat (Puskesmas) setempat dalam melakukan bantuan pemeriksaan kesehatan secara berkala. Pengelolaan layanan kesehatan secara mandiri belum bisa dilakukan dikarenakan biaya dan sumber daya manusia, fasilitas yang belum memadai. Sisi lain, layanan masalah psikologis masih mampu ditangani oleh guru bimbingan konseling, namun sifatnya masih sebatas penguatan individual bukan intervensi psikologis bagi siswa yang membutuhkan, sehingga perlu kiranya setiap sekolah dapat membangun jejaring kerja sama dengan himpunan profesi psikologi, atau setidaknya bekerja sama dengan biro psikologi di wilayah sekolah mereka masing-masing.

Status kesehatan siswa yang menjadi perhatian yaitu adanya penyakit infeksi pernafasan pada siswa yang sesekali ada, dan adanya gejala sakit leher/ bahu, gejala sakit perut, ketegangan dan kecemasan, iritasi, sakit kepala, dan gejala flu pada siswa yang terjadi dalam satu kali atau dan beberapa kali sebulan. A. I. Konu \& Lintonen (2006) menjelaskan bahwa gejalagejala ini adalah gejala umum yang dirasakan oleh siswa. Hal ini bukan hanya terjadi di tingkat sekolah menengah umum saja, namun juga pada sekolah dasar dan sekolah menengah pertama.
Gejala kesehatan umum ini merupakan masalah penting pada masa remaja, dan siswa sekolah menengah atas berisiko tinggi mengalami gangguan kesehatan ini. Upaya dalam menekan gejala ini diperlukan salah satunya merencanakan program konseling yang tepat, serta diperlukan evaluasi status kesehatan siswa secara berkala.

Implementasi program sekolah sejahtera tidak akan mungkin berjalan dengan efektif tanpa dukungan sekolah. Sekolah bukan hanya memiliki tanggung jawab terhadap pencapaian akademis namun juga terhadap kesejahteraan psikologis siswa. Beberapa hal yang perlu dimiliki sekolah yaitu kepemimpinan, rencana pengelolaan siswa, implementasi efektif, keterlibatan dewan pengawas sekolah. Lebih lanjut, kesiapan keuangan dan alokasi sumber daya manusia juga diperlukan dalam pelaksanaan sekolah sejahtera. Dalam penerapanya dewan pengawas sekolah harus memahami rencana keuangan untuk keberlanjutan jangka panjang sekolah dan kemudian mengawasi program ini, dan sekolah juga melibatkan lembaga swadaya manusia (LSM) dan Kementerian yang berbeda untuk implementasi dan keberlanjutan proyek sekolah sejahtera untuk mengumpulkan dana dan sumber daya (Zulfiqar et al., 2019) 


\section{SIMPULAN}

Program sekolah sejahtera bukan menjadi hal baru dalam pengembangan kesejahteraan psikologis siswa. Indikator capaian sekolah sejahtera di sekolah menengah umum Kota Jambi yang telah tercapai yaitu kondisi sekolah (having), hubungan sosial (loving), pemenuhan diri sekolah (being), status kesehatan (health) meskipun dalam setiap komponen masih ada status indikator capaian yang belum memuaskan.

\section{SARAN}

Implementasi program sekolah sejahtera menjadi tanggung jawab sekolah dan stakeholder dalam mewujudkan kesejahteraan psikologis siswa lebih optimal. Hal ini membutuhkan kerja sama lintas sektoral, baik itu melalui institusi level tingkat daerah, provinsi bahkan sampai Kementerian dalam mewujudkan program ini, terutama dalam kesiapan dana/ keuangan dan alokasi sumber daya manusia. Sekolah sebaiknya mulai mempersiapkan rencana pengelolaan mencakup tata kelola, rencana jangka panjang, sumber dana, implementasi, dan pengawasan dari dewan pengawas sekolah dan lembaga swadaya masyarakat (LSM), sehingga keberlanjutan program ini bisa berjalan sesuai indikator yang targetkan.

\section{DAFTAR RUJUKAN}

Barret, P., Treves, A., Shmis, T., Ambasz, D., \& Ustinova, M. (2018). The Impact of School Infrastructure on Learning.

Cuyvers, K., De Weerd, G., Dupont, S., Mols, S., \& Nuytten, C. (2011). WellBeing at School: Does Infrastructure Matter?. CELE Exchange.

Fadzlul, S., Saputra, N., Ekawati, Y., \& Periantalo, J. (2016). Identifikasi Faktor Protektif Dan Resiko Pada Siswa Di Kota Jambi. Jurnal Psikologi Jambi, 1(1), 1-9.

Fatmawati, S. (2018). Implementasi Program Sekolah Sejahtera Di SMA
Negeri 1 Godean the Implementation of the School Well-Being Program in Sma Negeri. JUrnal Kebijakan Pendidikan, 4, 201-211.

Gilman, R., \& Huebner, S. (2003). A review of life satisfaction research with children and adolescents. School Psychology Quarterly, 18(2), 192205.

https://doi.org/10.1521/scpq.18.2.192. 21858

Hidayah, N. H., Pali, M., Ramli, M., \& Hanurawan, F. (2016). Students' WellBeing Assessment at School. Journal of Educational, Health and Community Psychology, 5(1), 62. https://doi.org/10.12928/jehcp.v5i1.62 57

Jessor, R. (1993). Succesful adolescent development among youth in high-risk settings. American Psychological Association, 48(2), 117-126.

Keyes, C. L. M., \& Waterman, M. B. (2008). Dimensions of well-being and mental health in adulthood. Dalam Marc H. Bornstein, dkk. (Ed), WellBeing: Positive development across the life course. New Jersey, NJ: Lawrence Erlbaum Associates, Inc

Khatimah, H. (2015). Gambaran School Well-Being pada Peserta Didik Program Kelas Akselerasi di SMA $\begin{array}{lll}\text { Negeri } & 8 & \text { Yogyakarta. }\end{array}$ PSIKOPEDAGOGIA Jurnal Bimbingan Dan Konseling, 4(1), 20. https://doi.org/10.12928/psikopedagog ia.v4i1.4485

Konu, A. I., \& Lintonen, T. P. (2006). School well-being in Grades 4-12. Health Education Research, 21(5), 633-642.

https://doi.org/10.1093/her/cyl032

Konu, A., \& Rimpelä, M. (2002). Wellbeing in schools: A conceptual model. Health Promotion International, 17(1), 79-87.

https://doi.org/10.1093/heapro/17.1.79

Kuusimäki, A. M., Uusitalo-Malmivaara, 
L., \& Tirri, K. (2019). The Role of Digital School-Home Communication in Teacher Well-Being. Frontiers in Psychology, 10(November), 1-8. https://doi.org/10.3389/fpsyg.2019.022 57

Laho, N. (2019). Enhancing School-Home Communication through Learning Management System Adoption: Parent and Teacher Perceptions and Practices. School Community Journal, 29(1), 117-142.

Lohmeier, J. H., \& Lee, S. W. (2011). A school connectedness scale for use with adolescents. Educational Research and Evaluation, 17(2), 8595.

https://doi.org/10.1080/13803611.2011 .597108

McLaughlin, C. (2008). Emotional wellbeing and its relationship to schools and classrooms: A critical reflection. British Journal of Guidance and Counselling, 36(4), 353-366. https://doi.org/10.1080/030698808023 64486

Muis, T. (2017). Tindakan Kekerasan Guru Terhadap Siswa dalam Interaksi Belajar Mengajar (Studi Kasus di SMAN Surabaya). Jurnal Pendidikan (Teori Dan Praktik), 2(1), 86. https://doi.org/10.26740/jp.v2n1.p8690

Owoeye, J. S., \& Yara, P. O. (2011). School facilities and academic achievement of secondary school agricultural science in Ekiti state, Nigeria. Asian Social Science, 7(7), 64-74. https://doi.org/10.5539/ass.v7n7p64

Palt, K., \& Harro-Loit, H. (2015). Parentteacher communication patterns concerning activity and positivenegative attitudes. Trames, 19(3), 249272.

https://doi.org/10.3176/tr.2015.2.03

Supriatna, M. (2017). Efektivitas model konseling aktualisasi diri untuk mengembangkan kecakapan pribadi. Jurnal Psikologi Pendidikan Dan Konseling: Jurnal Kajian Psikologi Pendidikan Dan Bimbingan Konseling, $3, \quad 11$. https://doi.org/10.26858/jpkk.v0i0.297 3

Zulfiqar, A., Syed, F. R., \& Latif, F. F. (2019). Developing a student wellbeing model for schools in Pakistan. Improving Schools, 22(1), 86-108. https://doi.org/10.1177/136548021879 4755 